\title{
ASSESSMENT OF THE MICROBIAL QUALITY AND AFLATOXINS CONTENT IN POULTRY FARMS EGGS SOLD IN QENA CITY- UPPER EGYPT
}

\author{
LAILA M. EL MALT
}

Department of Food Hygiene, Faculty of Veterinary Medicine, South Valley University, Qena Upper Egypt.

\section{ABSTRACT}

Received at: 31/3/2015

Accepted: 11/5/2015
Contamination of eggs with microorganisms that possibly affect eggs quality and transmit pathogens or intoxication to consumers, causing public health hazards. A total of 135 fresh poultry farms eggs were collected randomly from different groceries and markets in Qena city, Upper Egypt. Every three eggs from each market were represented as one egg pooled sample $(n=45$ pools $)$ Each egg shell and content was examined for their microbiological contents in terms of aerobic plate, enterococci, total coliforms, faecal coliforms and yeast and mold counts $/ \mathrm{ml}$, presence of salmonella, Escherichia coli, Listeria, and the presence of total aflatoxins (AFs) levels by enzyme linked immune-sorbent assay (ELISA). The results showed microbial growth on $100 \%$ of each (45 shell and content pools) of the examined samples and of all, total aflatoxin contamination was determined to trace amounts in three egg samples $(6.7 \%$ ) (ranging from 0.7 to $1.15 \mathrm{ppb}$ ). Other samples tested were found to be free from any detectable level of aflatoxins. Among poultry farms hen eggs average values of aerobic plate, enteroccocci and total yeast and mold counts / $\mathrm{ml}$ of egg shells samples were $6.16 \mathrm{X} 10^{3}, 1.6 \times 10^{2}$ and $2.50 \times 102$ cells/ $\mathrm{ml}$, respectively. However in egg contents, the corresponding counts were lower than that of egg shells samples 1.14 X103, - and 5.14 x10 cells $/ \mathrm{ml}$. Moreover, E. coli was found to be the most prevalent strain recovered from shell but not be detected in contents. The contamination by S. aureus were in $15(33.3 \%)$ and $9(20$ $\%)$ in shells and contents samples, respectively. Also one egg shell sample was contaminated by Listeria monocytogene and salmonella negative. It is concluded that eggs sold in Qena city were of good quality, although occurrence of some pathogenic microorganisms. Therefore, it is recommended that poultry farm hen eggs should not be consumed raw.

Key words: Microbial quality, Aflatoxins, Poultry farms, Eggs, Upper Egypt.

\section{INTRODUCTION}

Today, eggs remain a staple food within the human diet, consumed by people throughout the world. They are consumed worldwide in various dishes and considered very nutritious and a cheap source of protein. Though eggs are considered as complete food for growth and sustenance, studies indicated that microorganisms often contaminate eggs (Osei-Somuah et al., 2003).

Freshly laid eggs are generally devoid of organisms. However, following exposure to environmental conditions (for example, soil, dust and dirty nesting materials), eggs become contaminated with different types of microorganisms (Ellen et al., 2000). Furthermore, these microorganisms may contaminate the egg contents either by penetration or withdrawal through pores of the shells (Schoeni et al., 1995), and also through the transovarian route (Bruce and Drysdale, 1994). Some other factors such as environmental temperature and humidity influence the bacterial penetration and thus, enhance the infection and spoilage (Theron et al., 2003).

Food-borne diseases caused by microorganisms are a large and growing public health problem. Contamination of eggs and egg products with microorganisms can affect egg quality, which may lead to spoilage and pathogen transmission. This may induce cases of food-borne infection or intoxication to consumers, which constitute public health hazards. Several pathogenic microorganisms have been isolated from the surface of egg shells and contents.. Among them, Listeria monocytogenes, Yersinia enterocolitica, Escherichia coli, Salmonella and Campylobacter were detected (Adesiyun et al., 2005). 
Aflatoxins contaminate a vast array of foods and agriculture commodities, and produced by certain species of fungi. Such mycotoxins pose profound challenges to food safety widespread in many countries, especially in tropic and subtropical regions where temperature and humidity conditions are optimum for growth of moulds and production of toxins. The possible transmission of such toxic residues to edible eggs results in potential hazards to human health (Martins et al., 1998). Aflatoxin are known to be human carcinogens based on sufficient evidence of carcinogenicity in humans (Yaling et al., 2008).

Because of the continuous consumers demands worldwide to eggs periodical assessment is required to offer safe and good quality eggs for consumption. The present investigation was therefore, planned to assess and interior quality of consumed eggs at retail levels in Qena city Upper Egypt. Microbiological quality, presence of food pathogens and total aflatoxin residues were investigated.

\section{MATERIALS and METHODS}

-Samples collection:

One hundred and thirty-five (135) fresh poultry farms hen eggs were collected randomly from different groceries and markets in Qena city, Upper Egypt. Every three eggs from each market were represented as one egg pooled sample. All 45 egg pooled samples were examined for microbial quality, total aflatoxins (AFs) as well as presence of Staph aureus, listeria. E.coli and Salmonella. Two sampling methods were utilized.

I- Preparation of egg shell samples: Rinse solution method was carried out as reported by Perales and Audicana (1989).

II- Preparation of egg content samples: The eggs were prepared for evacuation of their contents according to Speck (1976).

- Experimental techniques:

Ten fold serial dilutions up to $10^{-6}$ were aseptically prepared from the rinse solution of egg shells, as well as, the homogeneous egg content samples. Then duplicate plating of $1 \mathrm{ml}$ aliquots used for enumeration of each analyzed microbial item. Each sample was divided into two parts, one for extraction of aflatoxins and the other for microbial enumeration, detection isolation and identification. Then subjected to the following examinations:

1- Aerobic plate count (A.P.H.A., 1992).

2- Enterococci count using KF Streptococcal agar (Deible and Hartman, 1976).
3- Total coliforms, faecal coliforms and E. coli using three tubes Most Probable Number (MPN) technique was employed (FAO, 1992). MPN was streaked on to Eosin Methylene Blue (EMB, OXOID, England). Typical isolates of E. coli were confirmed based on their IMVIC pattern according to Koneman et al. (2005).

4- Enumeration and isolation of viable yeast and mold using Sabourauds dextrose agar (Mislivec et al., 1992). The isolated fungi were identified according to different guidelines adopted by Raper and Fennell (1965); Pitt and Hocking (1997) and Klich (2002).

5- Isolation and identification of Staph. aureus.

- Enrichment procedure, loopful of the incubated broth was streaked into plates of selective media" Baired Parker agar" (Finegold and Martin, 1982).

- The identification was carried out using Gram staining, production of coagulas, catalase and fermentation of mannitol (Bennett and Lancette, 1995).

6- Isolation and identification of Listeria species.

- Enrichment procedure: $1 \mathrm{ml}$ of each rinse solution, as well as, from homogenous egg contents was placed aseptically in the Listeria enrichment broth. - Plating using Palcam medium (Curtis et al., 1989).

- Identification and species differentiation were carried out (Warburton et al., 2003) including Gram staining, Catalase teste, Carbohydrate fermentation, B-haemolysis on blood agar and CAMP test.

7- Isolation and identification of Salmonella.

- Pre-enrichment

- Selective- enrichment according to Rappaport et al. (1956).

- Selective plating using Xylose Lysine Desoxycholate agar (XLD; Oxoid).

- Identification of isolates.

- Morphological examination (A.P.H.A., 1992) motility test (Baron et al., 1994).

- Biochemical identification by hydrolysis of Christensen urea agar (Koneman et al., 1992), triple sugar iron (TSI) agar reaction (Baron et al., 1994), Gelatin liquefaction test (Quinn et al., 1994) Indole test, Methyle red test, Voges Prskauer test, citrate utilization test (Koneman et al., 1992) and sugar fermentation reaction (A.P.H.A., 1992).

- Serological identification according to Kauffmann. (1974).

- Detection of aflatoxins

MaxSignal ${ }^{\circledR}$ Aflatoxin Total- enzyme linked immunosorbent assay (ELISA) Test kit (Bio Scientific corp., Austin, TX, USA) is a competitive enzyme immunoassay and was used for the quantitative detection of AFs in the samples following manufacturer instructions. The micro wells were measured at $450 \mathrm{~nm}$ by ELISA reader (Elx800, Bio 
Tekinc., Highland Park, Winooski, VT, USA). The optical densities of the samples were determined and compared with that of the kit standard. Egg samples were exposed to some pretreatments the egg pooled samples were diluted with $70 \%$ methanol (1:9) mixed and blended for one min. The homogenate was filtered and $50 \mu \mathrm{l}$ of the filtrate was used per well for the assay. The test kit detection limit is $0.05 \mathrm{ng} / \mathrm{g}$ (ppb).

\section{RESULTS}

Table 1: Statistical analyticalresults of various microorganisms recovered from the examined poultry farms egg shells / ml.

\begin{tabular}{|c|c|c|c|c|c|c|}
\hline \multirow[t]{3}{*}{ Types of microorganisms } & \multirow{3}{*}{$\begin{array}{l}\text { No. of examined } \\
\text { samples }\end{array}$} & \multicolumn{2}{|c|}{ Positive samples } & \multicolumn{3}{|c|}{ Counts $/ \mathrm{ml}$ of positive samples } \\
\hline & & \multirow[t]{2}{*}{ No. } & \multirow[t]{2}{*}{$\%$} & & & \\
\hline & & & & Min & Max & average \\
\hline Aerobic plate counts & 45 & 45 & 100 & 500 & 17600 & $6.16 \times 10^{3}$ \\
\hline Enterococci counts & 45 & 2 & 4.4 & 100 & 220 & $1.60 \times 10^{2}$ \\
\hline Yeast and mold counts & 45 & 30 & 66.66 & 100 & 500 & $2.50 \times 10^{2}$ \\
\hline
\end{tabular}

Table 2: Statistical analytical results of various microorganisms recovered from the examined poultry farms hen egg contents / $\mathrm{ml}$.

\begin{tabular}{ccccccc}
\hline Types of microorganisms & $\begin{array}{c}\text { No. of examined } \\
\text { samples }\end{array}$ & Positive samples & \multicolumn{2}{c}{ Counts /ml } \\
\cline { 3 - 6 } & & No. & $\%$ & Min & Max & $\begin{array}{c}\text { Average of positive } \\
\text { samples }\end{array}$ \\
\hline Aerobic plate counts & 45 & 45 & 100 & 10 & 4000 & $1.14 \times 10^{3}$ \\
\hline Enterococci counts & 45 & - & - & - & - & - \\
\hline Yeast and mold counts & 45 & 21 & 46.6 & 10 & 100 & $5.14 \times 10$ \\
\hline
\end{tabular}

Table 3: Frequency distribution of the positive shells and contents Poultry farms egg samples based on their total coliform, Fecal coliform and E. coli counts.

\begin{tabular}{|c|c|c|c|c|c|c|c|c|c|c|c|c|}
\hline \multirow[t]{3}{*}{ Count/ml } & \multicolumn{6}{|c|}{ Poultry farms egg shells } & \multicolumn{6}{|c|}{ Poultry farms egg contents } \\
\hline & \multicolumn{2}{|c|}{ Total coliform } & \multicolumn{2}{|c|}{ Fecal coliform } & \multicolumn{2}{|c|}{ E.coli } & \multicolumn{2}{|c|}{ Total coliform } & \multicolumn{2}{|c|}{ Fecal coliform } & \multicolumn{2}{|c|}{ E.coli } \\
\hline & No./21 & $\%$ & $\mathrm{No} / 15$ & $\%$ & $\mathrm{No} / 9$ & $\%$ & $\mathrm{No} / 12$ & $\%$ & $\mathrm{~N} 0 / 9$ & $\%$ & $\mathrm{No} /$ & $\%$ \\
\hline $3-$ & 8 & 38.7 & 5 & 33.3 & 6 & 66.6 & 6 & 50 & 9 & 100 & - & - \\
\hline $10^{1-}$ & 4 & 19 & 10 & 66.7 & 3 & 33.3 & & & & & & \\
\hline $10^{2-}$ & 9 & 42.9 & & & & & 3 & 25 & & & & \\
\hline $10^{3-}$ & & & & & & & 3 & 25 & & & & \\
\hline Total & 21 & 100 & 15 & 100 & 9 & 100 & 12 & 100 & 9 & 100 & - & \\
\hline
\end{tabular}

Table 4: Incidence of Staph aureus and Sal. Spp. Isolated from the examined poultry farms egg samples.

\begin{tabular}{cccccccc}
\hline \multirow{2}{*}{ Egg samples } & \multicolumn{4}{c}{ Staph. spp. } & \multicolumn{2}{c}{ Sal. spp. } \\
\cline { 2 - 6 } & \multicolumn{2}{c}{ Staph. aureus } & \multicolumn{2}{c}{ CNS } & No/45 & $\%$ \\
\cline { 2 - 7 } & No./45 & $\%$ & No./ 45 & $\%$ & 0 & 0 \\
\hline Shells & 15 & 33.3 & 7 & 15.55 & 0 & 0 \\
\hline Contents & 9 & 20 & 4 & 8.9 & 0 & 0 \\
\hline Total & 24 & 53.3 & 11 & 24.4 & & 0 \\
\hline
\end{tabular}

$\mathrm{CNS}=$ coagulase negative Staph. aureus 
Table 5: Incidence of. Listeria species recovered from the examined poultry farms egg samples.

\begin{tabular}{ccccc}
\hline Listeria species & \multicolumn{2}{c}{ Egg shells } & \multicolumn{2}{c}{ Egg contents } \\
\cline { 2 - 5 } & \multicolumn{2}{c}{ Positive samples } & \multicolumn{2}{c}{ Positive samples } \\
\cline { 2 - 5 } & No/45 & $\%$ & No./45 & $\%$ \\
\hline L. monocytogene & 1 & 2.2 & 0 & \\
\hline L. innocua & 0 & 0 & 0 \\
\hline L.seeligri & 0 & 0 & 0 \\
\hline L.gray & 4 & 8.9 & 0 \\
\hline
\end{tabular}

Table 6: Incidence of fungi recovered from the examined poultry farms eggs samples.

\begin{tabular}{ccccc}
\hline Fungal species & \multicolumn{2}{c}{ Egg shells } & \multicolumn{2}{c}{ Egg contents } \\
\hline & No/45 & $\%$ & No/45 & $\%$ \\
\hline Aspergillusflavus & 6 & 13.3 & 4 & 8.9 \\
\hline Aspergillusniger & 2 & 4.4 & 1 & 2.2 \\
\hline Aspergillusfumigatus & 5 & 11.11 & 2 & 4.4 \\
\hline Penicillium spp. & 2 & 4.4 & 1 & 2.2 \\
\hline Cladosporium spp. & 8 & 17.8 & 2 & 4.4 \\
\hline Mucor spp. & 4 & 8.9 & 0 & 0 \\
\hline Total & 27 & 60 & 10 & 22.2 \\
\hline
\end{tabular}

Table 7: Results of AFs content residues in the examined poultry farms egg samples.

\begin{tabular}{lcccc}
\hline Examined samples & $\begin{array}{c}\text { Total No. of } \\
\text { samples }\end{array}$ & $\begin{array}{c}\text { No. of } \\
\text { positive }\end{array}$ & $\%$ & AFs concentration (ug /g or ppb of egg content) \\
\hline Poultry farms eggs & 45 & 3 & 6.7 & $(0.71,0.81,1.15)$ \\
\hline
\end{tabular}

\section{DISCUSSION}

Results presented in Table 1, declared that the average counts of aerobic plate, enterococci, and yeast and mold $/ \mathrm{ml}$ of the rinsing solution of the examined poultry farms hen eggs shell samples were $6.16 \times 10^{3}, 1.60 \times 10^{2}$, and $2.50 \times 10^{2}$, respectively.

The average aerobic plate counts were $6.16 \times 10^{3}$ and $1.14 \times 10^{3}$ for shell and content of poultry farms hen eggs less than accepted $10 \times 10^{5} \mathrm{cfu} / \mathrm{ml}$ as recommended by the international commission on the microbiological specification for food (ICMSF 1998).

The most important index of microbiological quality is aerobic plate counts, enterococci, total coliforms, faecal coliforms, yeast and mold detection of specific pathogens and their toxins is recorded by A.P.H.A (1992) as the microbial quality reflected the care with which poultry farms hen eggs were handled and stored.

In addition from the data recorded in Table 2 , it is evident that the average values of the aforementioned fresh homogenous contents were lower than that of examined poultry farms hen eggs shell. This finding substantiates what has been postulated by Labaque et al. (2003); Jones et al. (2004) and Bahobail et al. (2012). Moreover, Humphrey (1994) reported that the final microbial load of egg contents depends on temperature and length of storage.

The results given in (Table1-2) pointed out that the average value of enterococci was $1.60 \times 10^{2}$ in examined poultry farms hen eggs shell which failed to be detected in hen egg contents these result lower with those staled with El- Prince et al. (2003). Moreover, E. coli filed to detect in contents these 
results agree to a certain extant with those obtained by Seleim and El- Prince (2000) in chicken eggs and El- Prince et al. (2003) in quail eggs. Also the results pointed out that E.coli was recovered from the eggs shell in a percentage of $20 \%$ however E.coli could not be detected in eggs content. In contrast, the contamination of egg shell and content with E. coli was previously investigated by Abdel -Hady and Emara (1997) and Moustafa et al. (2001), Sabreen (2001) also could isolate E.coli in an incidence of 5\% from examined infertile quail eggs while $\mathrm{El}$-Prince et al. (2003) found E.coli in egg shell in a percentage of 6\% from quail eggs and Bahobail et al. (2012) found $3(7 \%)$ of ( $n=45$ pooled samples) had E. coli in their shells but not in the egg content in chicken eggs. It has been stated that avian pathogenic E.coli causes airsacculitis, polyserositis, septicemia and other avian species. Avian pathogenic E.coli is found in the intestinal microflora of healthy birds and most of the disease associated with them are secondary to environmental and host predisposing factors (DhoMoulin and Fairbrother, 1999). They also added that prevention and control of these infections include control humidity and ventilation.

The results in Table 3, revealed that the highest frequency distribution of positive samples of total coliform in poultry farms hen eggs shell were $42.9 \%$ lied in the range of $10^{2}-<10^{3} \mathrm{cfu} / \mathrm{ml}$ while in contents were $50 \%$ lied in the range of $3->10 \mathrm{cfu} / \mathrm{ml}$. The rest of the positive samples of total coliforms in shells were distributed as $38 \%$ and $19 \%$ lied between $3->10$ and $10^{1}>10^{2} \mathrm{cfu} / \mathrm{ml}$. Otherwise the highest frequency distribution of positive samples of fecal coliforms in shells were $66.6 \%$ lied in the range of $10^{1}->10^{2} \mathrm{cfu} / \mathrm{ml}$ and in contents were $100 \%$ lied in range of $3-<10$ while the highest frequency distribution of positive samples of E. coli in shells were 66.6 lied between $3-<10$ and in contents failed to be detected.

A health issue associated with poultry farms hen eggs is their contamination by pathogenic bacteria in this study Table 4, Staph. aureuswas recovered from 15 $(33.3 \%$ ) and $9(20 \%)$ of the total examined shells and contents of poultry farms hen eggs, respectively. As well the Staph.aureus scored lower percentage of contamination than that recorded by Korashy et al. (2008) and El -Malt (2013). From Table 4, the low incidence of Staph.aureus in the egg contents may be due to the presence of lysozyme in the inner shell membrane which act as an effective agent against Gram positive organisms. Regarding CNS, they were isolated from shell surfaces, $7(5.55 \%)$ and 4 egg contents $(8.9 \%)$ samples contamination.

In this study isolated L. monocytogenes from the egg shells (1of 45 samples) but not from egg contents. While L. gray was detected in examined eggs with low ratio 4 samples $(8.9 \%)$ of 135 poultry eggs $(n=45$ samples) in their shells but not in the contents Table 5, El-Malt, and Abdel-Hameed (2009) examined table eggs obtained L. gray ratio $13.33 \%$ in egg shells and 11.71 in egg contents. The presence of Listeria species other than L. monocytogenesas indicators of the presence that organisms have been proposed Johnson et al. (1990). The presence of other Listeria species could be attributed to unsanitary measures during handling and transportation of eggs. Similar prevalence was found by Nitcheva et al. (1990) who isolated L. monocytogenes from the egg shells (1of 71 samples) but not from egg contents. In contrast, $L$. monocytogens was isolated with high frequency from samples of eggs collected at processing plants Leasor and Foegeding (1989) from the outer surface of the egg shells Likewise, Farber et al. (1992). Sayedetal. (2009) found that egg shells were contaminated with $7 \%$ of Listeria spp. while no contamination was found in egg contents. On the other hands, Moore and Madden (1993) recorded that $72 \%$ of raw blended egg samples were positive for Listeria spp. which $37.8 \%$ were identified as L. monocytogenes.

Failure to isolate Salmonella spp. from poultry farms eggs in the current study may due to strict control measures applied against these bacteria. Similarly, Salmonella was absent in all samples analyzed by Favier et al. (2000) and Anon (2004). Other studies reported variable and very low incidence of Salmonella in eggs. Begum et al. (2010) only isolated three Salmonella strains out of 1100 domestic eggs. Also, Musgrove et al. (2005) identified one out of 105 Enterobacteriaceae isolates, recovered from 84 shell surfaces, as Salmonella. Poppe et al. (1998); De Reu et al. (2006) and de Boer and Witt. (2000) reported that 0.07 to $0.4 \%$ (egg shell and egg content), $0.18 \%$ and $0.03 \%$ of table eggs, respectively were Salmonella-positive. This variability in Salmonella occurrence may be due to sample size, timing of sampling, sites of the eggs that were tested, techniques used, and investigations of eggs lay by artificially or naturally infected hens (Humphrey, 1994).

The fungal load found averaged $2.50 \times 10^{2} \mathrm{cfu} / \mathrm{ml}$ in eggs shells while averaged $5.14 \times 10 \mathrm{cfu} / \mathrm{ml}$ in the contents (Tables 1- 2). However, lower fungal count was reported in table eggs Ahmed et al. (2002); Suba et al. (2005) and Salem et al. (2009) which were reported to be $>5 \log { }_{10} \mathrm{cfu} / \mathrm{ml}$. Other studies indicated lower count of $1 \log _{10} \mathrm{cfu} / \mathrm{ml}$ in egg samples Ahmed et al. (1987) and El- Essawy et al. (1989). Jones et al. (2004) found an average fungal concentration of $1.5 \mathrm{log} \mathrm{cfu} / \mathrm{ml} \mathrm{egg}$ shell in the day of egg collections while averaged $0.1 \mathrm{log} \mathrm{cfu} / \mathrm{ml}$ in the content, while Bahobail et al. (2012), the fungal load found averaged $1.3 \log _{10} \mathrm{cfu} / \mathrm{ml}$.

It is apparent from results outlined in Table 6, that 27 $(60 \%)$ and $10(22.2 \%)$ fungi species belong to 4 
genera were presented in samples of shells and contents, respectively. Aspergilluswas the most prevalent genus constituting $13(28.9 \%)$ and $7(15.55 \%)$ in eggs shell and content, respectively. It was represented by 3 species, Aspergillusflavus $6(13.3 \%)$ and 4(8.9), Aspergillusniger 2(4.4\%) and 1(2.2), and Aspergillus fumigates5 (11.1\%) and 2(4.4) in egg shells and contents, respectively. However the genus Cladosporium ranked second in percentage of isolation constituting 8 (17.8) and 2(4.4) in shells and contents poultry farms samples, respectively. Furthermore, Penicillium spp. 2(4.4) and 1(2.2) in egg shells and contents, respectively. And Mucorisolated from examined shells only. Mycological examination in the current work revealed four genera, which agrees with published reports where Aspergillus spp., Penicillum spp., cladosporum spp. And Mucorspp. have been recovered from washed eggs or their contents (Salem et al., 2009; bahobail (2012).

In Table 7, The AFs contamination was detected to trace amounts only in three $(6.7 \%)$ of egg samples ranged 0.7 to $1.15 \mathrm{ppb}$. The positive samples did not exceed the maximum residual limits of aflatoxins recommended by WHO (2005) which is 5 ppb. Similar findings were reported by Ahmed et al. (2002), Aly and Anwer (2009), Salem et al. (2009), bahobail (2012) were aflatoxin contamination of egg was minimal comparing with the limit recommended by WHO (2005).

In CONCLUSION, the results showed that eggs of Qena city market are generally in a good quality, however because of the presence of minimal pathogenic microorganisms in some samples, we recommended that poultry farms eggs should not be consumed raw.

\section{REFERENCES}

A.P.H.A. (1992): Compendium of Methods for the Micobiological Examination of Foods. $2^{\text {nd }}$ Ed.American Public Health Associiation, Washington, DC., USA.

Abdel-Hady, H.M. and Emara, M.M.T. (1997): Hazard analysis critical point evaluation of egg and bastermameal. Alexander J. Vet. Sci., 13(1): 63-73.

Adesiyun, A.; Offiah, N.; Seepersadsingh, N. and Rodrigo, S.K. (2005): Microbial health risk posed by table eggs in Trinidad. Epidemiol. Infect., 133 Lashley V, Musai L, Georges: 1049-1056.

Ahmed, H.F.; Deeb, M.M.A. and Aman, I.M. (2002): Studies on market hen eggs in kafr El-sheikh and El- Gharbia Governorates. Vet. Med. J. Giza, 50: 610-615.
Ahmed. A.A.H.; Saad, Nagah, M. and Moustafa, M.K. (1987): Microbial contamination of market hen eggs. Assuit Vet. Med. J., 18: 36.

Aly, S.A. and Anwer, W. (2009): Effect of Naturally Contaminated Feed with Aflatoxins on Performance of Laying Hens and the Carryover of Alatoxin B1 Residues in Table Eggs. Pakistan J. Nutr., 8: 181-186.

Anon (2004): Report of the survey of Salmonella contamination of UK produced shell eggs on retail sale. London, Food Standard Agency, pp. 124. Assuit Vet. Med. J., 59 (139): 99-106.

Bahobail, A-A.S.; Hassan, S.A. and El-Deeb, B.A. (2012): Microbial quality and content aflatoxins of commercially available eggs in Taif, Saudi Arabia. African Journal of Microbiology Research, 6(13): 3337-3342.

Baron, Ellen, I.O.; Perteson, I.R. and Finegold, Sydney, M. (1994): Bailey and scott"s Diagnostic Microbiology. $9^{\text {th }}$ ed Shanahan J.F. (Ed.). Mosby Year Book, Inc.

Begum, K.; Reza, T.A.; Hague, M.; Hossain, A.; Hassan, F.M.K.; Hassan, S.N.; Akhter, N.; Ahmed, A. and Barua, U. (2010): Isolation, identification and antibiotic resistance pattern of Salmonella spp. from chicken eggs, intestines and environmental samples. Bangladesh Pharmaceut. J., 13: 23-27

Bennett, R.W. and Lancette, G.A. (1995): Staphyloccusaureus. Chapter 12, In:Food and Drug Administration Bacteriological Analytical Manual. $8^{\text {th }}$ ed., AOAC International, Gaithersburg, MD.: 12. 01-12. 05.

Bruce, J. and Drysdale, E.M. (1994): Trans-shell transmission. In: Microbiology of the avian egg (Es. Board R. G. and R. Fuller). London: Chapman and Hall, pp. 63-91.

Curtis, G.D.W.; Mitchell, R.G.; King, A.F. and Griffan, E.J. (1989): A selective differential medium for the isolation of L. monocytogenes. Lett. Appl. Microbiol., 8: 95 -98.

De Boer, and Witt, B. (2000): Salmonella in eggs. Tijdschriftvoor Diergeneeskunde, 125: 126-127.

De Reu, K.; Heyndrickx, M.; Grijspeerdt, K.; Rodenburg, B.; Tuyttens, F.; Uyttendaele, M.; Debevere, J. and Herman, L. (2006): Assessment of the vertical and horizontal aerobic bacterial infection of shell eggs. World's Poultry Sci. J., 62: 564.

Deible, R.H. and Hartman, P.A. (1976): The Enterococci In: Compendium of Methods for the Microbiological Examination of Foods, M.L. Speck (Ed.) $2^{\text {nd }}$ ed, American Public Health Association, Inc

Dho-Moulin, M. and Fairbrother, J.M. (1999): Avian pathogenic Escherichia coli (APEC). Vet. Rec., 30(2-3): 299-316. 
El Malt, Laila, M. (2013): An assessment of the microbiological risks involved with quail eggs Qena city Upper Egypt. Assiut Vet. J. Vol. 59, No.159 PP.99-106.

El-Essawy, H.A.; Saudi, A.M. and Sallam, S.S. (1989): Microbiological studies on market hen eggs. Alexanderia Vet. Sci. J., 5: 219-225.

Ellen, H.H.; Bottcher, R.W.; Von Wachebfelt, E. and Takai, H. (2000): Dust levels and control methods in poultry houses. J. Agri. Safety Health, 6: 275-282.

El-Malt, Laila, M. and Abdel-Hameed, K. Galal (2009): Prevalence and health status of Listeria species in hen's eggs in Qena governorate. Zagzig Vet. J. (ISSN.1110-1458) Vol.37, No. 3 pp. 1-6.

El-Prince, Enas; Khalifa, A.H.A. and El-Dengawy, R.A.H. (2003): Assessment of physical and nutritional properties with microbiological quality of Japanese quail eggs. $2^{\text {nd }}$ ICOFHHH; 21-23 October 2003, Assiut-Egypt. 6: 234-241.

FAO "Food and Agriculture Organization" (1992): Manual of Food Quality Control. 4. Rev. 1. Microbiological analysis.Food and Agriculture Organization of the United. Nations. Rome, Italy.

Farber, J.M.; Daley, E. and Coates, F. (1992): Presence of Listeria spp. in whole eggs and wash water samples from Ontario and Quebec. Food Res. Intl., 25: 143-145.

Favier, G.I.; Escudero, M.E.; Velazquez, L. and de Guzman, A.M.S. (2000): Reduction of Yersinia enterocolitica and mesophilic aerobic bacteria in egg-shell by washing with surfactants and their effect on the shell microstructure. Food Microbiol., 17: 73-81.

Finegold, S.H. and Martin, W.J. (1982): Diagnostic Microbiology. Baillyand Scott. $6^{\text {th }}$ ed. Mosby Co. St., Louis, Toronto. London.

Humphrey, T.J. (1994): Contamination of egg shell and contents with Salmonella enteritidis: a review. Int. J. Food Microbiol., 21: 31-40.

ICMSF (International Commission on Microbiological Specification for Foods) (1998): Microorganisms in foods. Volume 6, Microbial ecology of food commodities. New York: Blackie Acad. Prof., pp. 615.

Johnson, J.L. and Doyle, M.P. (1990): Listeria monocytogens and other listeria species .In meat and meat products. A review J. food prot., 53(1): 81-81.

Jones, D.R.; Musgrove, M.T. and Northcutt, J.K. (2004): Variation in external and internal microbial populations in shell eggs during extended storage. J. Food Prot., 67: 2657-2660.

Kauffmann, F. (1974): Serological diagnosis of Salmonella species. Kauffman-White scheme. Minksgand, Copenhagen, Denmark.
Klich, M.A. (2002): Identification of common Aspergillus species. Utrecht, Netherlands: Centraalbureauvoor Schimmelcultures, pp.116.

Koneman, E.; Washington Winn, Jr.; Allen, S.; Janda, W.; Procop, G.; Paul, S. and Gail, W. (2005): Color Atlas and Textbook of Diagnostic Microbiology. 6th ed., Lippincott Williams and Wilkins Company. Philadelphia, USA.

Koneman, E.W.; Schreehenberger, P.C.; Allen, S.D.; Winn, W.C. and Janda, W.M. (1992): Colour atlas and textbook of diagnostic microbiology. $4^{\text {th }}$ ed. Winter, R. (Ed.), J.B. Lippincott company, Philadelphia.

Korashy, E.A.; Nahed, M.W. and Hassanein, $R$. (2008): Public Health Hazards of some bacterial pathogens associated with consumption of eggs and studying the best cooking methods for destruction. Assiut Vet. Med. J. 54(117).

Labaque, M.C.; Navarro, J.L. and Martella, M.B. (2003): Microbial contaminant of artificially contaminated Greater Rhea (Rhea Americana) eggs. Poult. Sci., 44: 355-358.

Leasor, S.B. and Foegeding, P.M. (1989): Listeria species in commercially broken raw liquid whole egg. J. Food Protect., 52: 777-780.

Martins, H.M.; Bernatdo, F.M. and Martins, M. L. (1998): Effect of Saccharomyces cerevisiae ATCC97631 on Aflatoxins production, $4^{\text {th }}$ World Cong. Foodborne Infection and Intoxication, pp. 7-12.

Mislivec, P.B.; Beuchat, L.R. and Cousin, M.A. (1992): Yeasts and Molds. Chapter 16.Compendium of Methods for Microbiological Examination of Food. Vanderzant, C. and Splitoesser, D. (Eds.), $3^{\text {rd }}$ ed., American Public Health Association, Washington, DC, USA.

Moore, J. and Madden, R.H. (1993): Detection and incidence of Listeria species in blended raw eggs. J. Food Prot., 56: 652-654.

Moustafa, Fatma, A.; Bastawrows, A.F.; Abd-ElGawad, A.M. and Halil, Nawal, Gh. (2001): Bacteriological studies on the causative agents of low hatchability and infertility of quail eggs in Assiut Vet. Med. J., 44 (88): 257-274.

Musgrove, M.T.; Jones, D.R.; Northcutt, J.K.; Cox, N.A. and Harrison, M.A. (2005): Shell rinse and shell crush methods for the recovery of aerobic microorganisms and Enterobacteriaceae from shell eggs. J. Food Prot., 68: 2144-2148.

Nitcheva, L.; Yonkova, V.; Popov, V. and Manev, C. (1990): Listeria isolation from foods of animal origin. Acta VeterinariaHungaria, 37: 223-225.

Osei-Somuah, A.; Otsyina, H.R.; Arthur, C.T.; Nortey, P.W.K and Hammond, V. (2003): Microbial quality of table eggs sold on 
selected markets in Accra. Ghana Vet. Med. Assoc. Bi-Annual Newslett., 6: 314-318.

Perales, I. and Audicana, A. (1989): The role of hens eggs in outbreaks salmonellosis in North Spain. Int. J. Food Microbiol., 8:175-180.

Pitt, J.I. and Hocking, A.D. (1997): Fungi and Food Spoilage, 2nd Ed. Blackie Academic Press, London. P. 504.

Poppe, C.; Duncan, C. and Mazzocco, A. (1998): Salmonella contamination of hatching and table eggs: a comparison. Can. J. Vet. Res., 62: 19-198.

Quinn, P.J.; Carter, M.E.; Markey, B.K. and Carter, G.R. (1994): Clinical Veterinary Microbiology. Mosby Year Book Europe limited.

Raper, K.B. and Fennell, D.I. (1965): The Genus Aspergilluss, Baltimore: Williams and Wilkins Company, pp. 686.

Rappaport, F.; Knforti, N. and Navon, B. (1956): New enrichment medium for certain Salmonella J. Clin. Pathol. 6: 261.

Sabreen, M.S. (2001): Search for some pathogenic bacteria in commercial hens and ducks eggs sold in Assiut Governorate. Assiut Vet. Med. J., 45(89): 91-103.

Salem, R.M.; El-Kaseh, R.M. and El-Diasty, E.M. (2009): A study on the fungal contamination and prevalence of Aflatoxins and some antibiotic residues in table eggs. Arab J. Biotech., 12: 65-72.

Sayed, M.; Abdel-Azeem, M.; Farghaly, M. and Hassanein, R. (2009): Using of PCR assay for identification of Listeria monocytogenes recovered from table eggs. Vet. World, 2: 453-455.
Schoeni, J.L.; Glass, K.A.; Mcdermott, J.L. and Wong, A.C.L. (1995): Growth and penetration of Salmonella enteritidis, Salmonella Heidelberg and Salmonella typhimurium in eggs. Int. J. Food Microbiol., 24: 385-396.

Seleim, Magda, A. and El-Prince, Enas, M. (2000): Effect of storage and boiling on some quality characteristics of eggs. Assiut J., Agric. Sci., 31(4): 1-15.

Speck, M.L. (Ed.) (1976): Compendium of Methods for Microbiological Examination of Food. American Public Health Association, Washington, D.C.

Suba, S.; Narahari, D. and Prabhakar, T.G. (2005): Microbial quality and safety of table eggs 8 of Eggsand Egg products Doorwerth. The Netherlands, pp. 23-260.

Theron, H.; Enter, P.V. and Lues, J.F. (2003): Bacterial growth on chicken eggs in various storage environments. Food Res. Int., 36: 969-975.

Warburton, D.; Boville, Ann Pagotta, F.; Daley Elaine and Chow Clindy (2003): The detection of Listeria Spp. In foods and environmental samples using palcam broth. Health products and food branch (HPFB) Ottawa, Ontario.

WHO, World Health Organization (2005): International health regulation. 2 nded.http://whqlibdocwho int / publication/ 2008/979241580410_ en g.pdf.

Yaling, W.; Tongjie, C.; Guozhong, L.; Chansons, Q.; Huiyong, D.; Meiling, Y.; Bert-Andree, Z. and Gerd, S. (2008): Simultaneous detection of airborne aflatoxin, Ochratoxin and zearalenone in poultry house by immune affinity column and high performance liquid chromatography. Environ. Res., 107: 139-144.

\section{تعيين الجودة الميكروبيولوجية ووجود الأقلاتوكسين في بيض مزارع الدجاج في مدينة قنا ـ مصر العليا

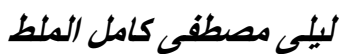

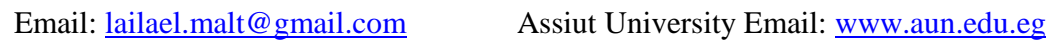

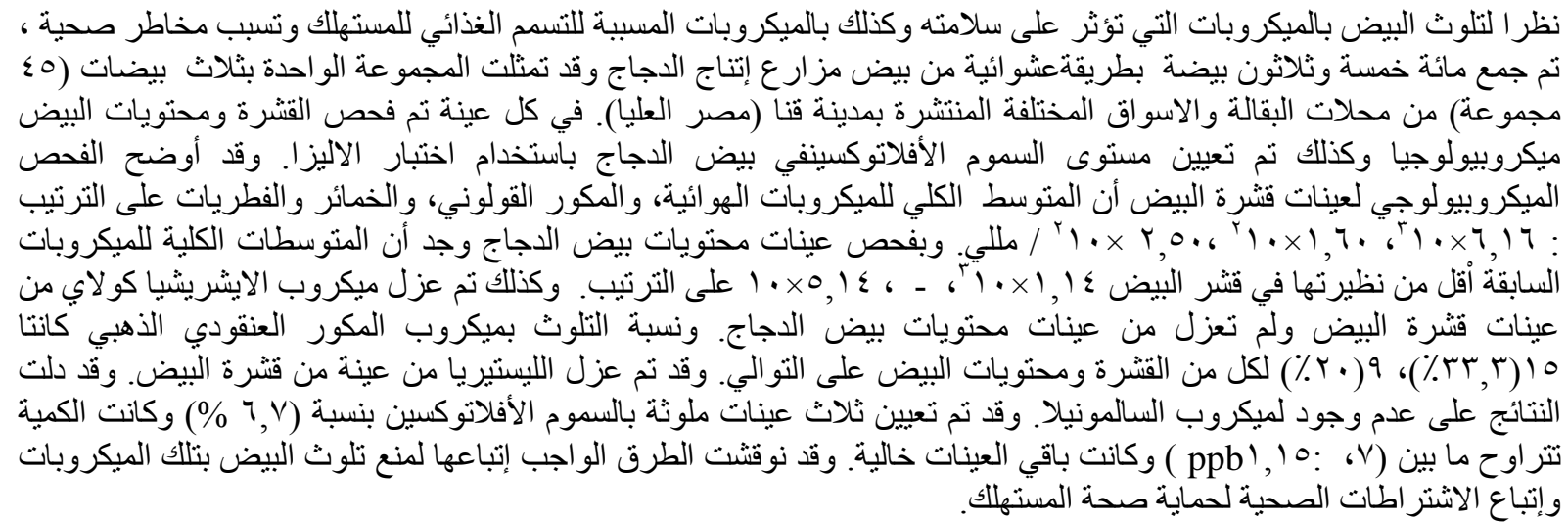

